\title{
Role of Lipoprotein Apheresis in Cardiovascular Disease Risk Reduction
}

\author{
Rupesh Raina ${ }^{a, c}$ Claire Young ${ }^{b}$ Vinod Krishnappa ${ }^{c, d}$ Rahul Chanchlani ${ }^{e, f}$ \\ a Department of Nephrology, Cleveland Clinic Akron General and Akron Children's Hospital, Akron, OH, USA; \\ ${ }^{\mathrm{b}}$ Michael G. DeGroote School of Medicine, McMaster University, Hamilton, ON, Canada; ${ }^{2}$ Akron Nephrology \\ Associates/Cleveland Clinic Akron General, Akron, OH, USA; ${ }^{d}$ Northeast Ohio Medical University, Rootstown, OH, USA; \\ e Division of Pediatric Nephrology, Department of Pediatrics, McMaster Children's Hospital, Hamilton, ON, Canada; \\ fDepartment of Health Research Methods, Evidence and Impact, McMaster University, Hamilton, ON, Canada
}

\section{Keywords}

Cardiovascular disease - Low-density lipoprotein .

Lipoprotein(a) · Lipoprotein apheresis · Atherosclerosis .

Peripheral vascular disease

\begin{abstract}
Background and Aim: Elevated low-density lipoprotein cholesterol and/or lipoprotein(a) are established risk factors for cardiovascular disease (CVD). Management of hypercholesterolemia consists of drug therapies, including statins and proprotein convertase subtilisin/kexin type 9 inhibitors. In patients with familial hypercholesterolemia $(\mathrm{FH})$, lipoprotein apheresis (LA) is utilized to control lipid levels. However, LA is not currently a standard therapy for non-FH. This review summarizes the literature regarding LA therapy in CVD prevention. Methods: PubMed/MEDLINE databases were searched using the keywords "LA" and "CVD". Citations were individually reviewed for relevance. Results: The efficacy of LA was clearly demonstrated, largely based on evidence from observational studies. In patients who are unresponsive to traditional lipid-lowering medications, LA effectively reduced serum lipoprotein levels and adverse cardiovascular events. Conclusion: It was concluded that LA is a safe and effective technique that could be considered in the manage-
\end{abstract}

\section{KARGER}

() 2019 S. Karger AG, Basel

E-Mail karger@karger.com

www.karger.com/bpu ment of hypercholesterolemia and future risk. Randomized control trials would further support a role for LA as a therapeutic option.

(c) 2019 S. Karger AG, Basel

\section{Introduction}

Approximately $11.5 \%$ (27.6 million) of American adults are suffering from heart disease. The American Heart Association (AHA) has estimated that by 2035, $45.1 \%$ of the US population will have some form of heart disease [1]. Important risk factors for cardiovascular disease (CVD) include high blood pressure, smoking, and high cholesterol, and $47 \%$ of Americans have at least one of these risk factors [2]. Following the discovery of the low-density lipoprotein (LDL) receptor [3] and advent of statins in the 1980s, reduction of high cholesterol levels has become an important therapeutic target in primary and secondary prevention of CVD. Numerous studies have confirmed elevated LDL as a well-established proatherogenic factor contributing to CVD $[4,5]$.

R.R. and C.Y. are first authors. 
LDL consists of a core component containing primarily cholesteryl esters, surrounded by a phospholipid monolayer and a single polypeptide chain of apolipoprotein B-100 (apoB-100) [6, 7]. It is the main transporter of plasma cholesterol, carrying approximately $65-70 \%$ [8]. Different LDL subtypes, dependent on size and composition, vary in atherogenic potential [9-11]. Smaller, dense LDL molecules are more associated with atherogenesis, increased triglyceride, and reduced high-density lipoprotein (HDL) levels, as well as metabolic syndrome and diabetic complications [11-14]. Dysregulation of cholesterol transport due to mutation of the LDL receptor or the apoB-100-binding protein, as is the case in familial hypercholesterolemia (FH), can lead to severely elevated levels of LDL and premature coronary artery disease (CAD) [3, $15,16]$.

In addition to LDL, evidence has indicated a role for lipoprotein(a) (Lp[a]) as a predictive factor for CVD [17, 18]. $\mathrm{Lp}(\mathrm{a})$ contains apoB-100, as well as an additional apo(a) [19]. The apo(a) chain differentiates $L p(a)$ from $\mathrm{LDL}$ and is similar in structure to plasminogen, a protein involved in fibrinolysis [20]. Lp(a) levels are heterogeneous in nature and determined genetically via the $L P A$ gene locus [21]. Specific single-nucleotide polymorphisms have been identified within this gene that influence baseline $\mathrm{Lp}$ (a) concentrations, with correlations to CAD [22]. The LDL receptor is not the primary receptor responsible for $\mathrm{Lp}(\mathrm{a})$ uptake from plasma [23]. Accordingly, $\mathrm{Lp}(\mathrm{a})$ levels do not respond well to statin therapy [24-26]. This paper will review the pathophysiology of LDL and Lp(a) in CVD, role and the current evidence surrounding lipoprotein apheresis (LA) in CVD risk reduction in patients with elevated LDL and/or Lp(a) levels.

The PubMed/MEDLINE database was searched using the terms "LDL apheresis" and "CVD" to look for studies regarding the use of LDL apheresis in CVDs. Citations were individually reviewed for relevance. Articles involving the use of LDL apheresis in non-CVD conditions were excluded. There is a lack of randomized control trials (RCTs) studying the efficacy of LA compared to standard lipid-lowering medical therapy. The majority of studies published are observational, either retrospective and/or prospective.

\section{Role of LDL and Lp(a) in CVD}

\section{Pathophysiology of LDL}

Many studies have confirmed an atherogenic role for LDL cholesterol. It is theorized that retention of lipopro- teins within the vasculature wall is the initiating event in atherosclerosis [27]. LDL can bind to vessel walls via an apoB-binding site, which interacts with extracellular matrix proteoglycans including decorin, biglycan, and syndecan-4 [28]. This lipid accumulation increases when circulating LDL levels are chronically elevated $[29,30]$. Retained LDL is modified to become oxidized-LDL (oxLDL), a necessary step for progression of atherosclerosis. OxLDL activates endothelial cells by inducing expression of cellular adhesion molecules, including P-selectin, allowing for migration of leukocytes into the endothelium [31]. Macrophage endocytosis of oxLDL leads to foam cell formation and subsequent appearance of fatty streaks within the vessel wall [32-34]. This process releases a number of cytokines involved in atherogenesis, including IFN-y, TNF-alpha, and IL-1 $[35,36]$. oxLDL can promote vascular smooth muscle cell proliferation, which migrate into the area forming a fibrous cap over the accumulation of lipids and foam cells $[37,38]$. Continued chronic inflammation causes macrophage and smooth muscle cell apoptosis, as well as proteolytic enzyme release leading to collagen degradation [39]. These processes create a vulnerable plaque at risk of rupture, creating the potential for adverse cardiac events.

\section{Cardiovascular Risk Associated with Elevated LDL}

Evidence of a link between elevated cholesterol and CVD has been well-established [4, 5]. Stamler et al. [4] screened 347,978 men from 1973 to 1975 with an average 12-year follow-up period for risk factors including diabetes mellitus, serum cholesterol levels, and smoking. It was concluded that serum cholesterol was a significant risk factor in cardiovascular mortality, in the presence/absence of diabetic comorbidity [4]. In 2016, the Prospective Studies Collaboration performed a meta-analysis of 61 prospective studies of vascular mortality, including 55,000 vascular deaths, and determined that total cholesterol levels were positively associated with vascular mortality due to ischemic heart disease [40]. Further studies have indicated a direct link between oxLDL and coronary heart disease risk, in elderly populations and those with metabolic syndrome [41-43].

The introduction of 3-hydroxy-3-methylglutaryl coenzyme A reductase inhibitors (statin) therapy allowed for definitive studies that correlate elevated LDL cholesterol levels with CVD risk. The Cholesterol Treatment Trialists' Collaboration published a landmark meta-analysis of statin therapies, in which they analyzed data from 90,056 participants in 14 randomized statin-based trials [44]. They demonstrated a $12 \%$ reduction in all-cause 
mortality per $\mathrm{mmol} / \mathrm{L}$ reduction in LDL cholesterol, noting a reduction of one-fifth $\mathrm{mmol} / \mathrm{L}$ LDL reduction could significantly reduce the 5-year incidence of cardiovascular events. A second meta-analysis published 5 years later compared more vs. less intensive statin therapy regimens [45]. It was demonstrated that a $1 \mathrm{mmol} / \mathrm{L}$ reduction in LDL cholesterol could reduce the annual rate of myocardial infarction and coronary artery revascularization by approximately $20 \%$.

Lastly, the link between elevated LDL and CVD is exemplified by inherited diseases causing aberrant LDL metabolism. FH is typically an inherited autosomal dominant disorder leading to defective clearance of LDL from the blood and is characterized by high circulating levels of LDL cholesterol [46]. Patients with homozygous or heterozygous $\mathrm{FH}$ are at increased risk for premature coronary heart disease and require screening and intensive LDL cholesterol-lowering therapy [47].

\section{Pathophysiology of Lp(a)}

Similar to LDL, oxidized Lp(a) (OxLp[a]) has a stronger role in atherogenesis than naïve (nonoxidized Lp[a]) [48]. OxLp (a) is shown to localize in endothelial cells early in the atherogenic process, implying that it may also be a part of the initial dysfunction in atherogenesis [49]. There are several additional parallels between Lp(a) activity and LDL activity in plaque formation, including macrophage endocytosis to form foam cells, endothelial cell activation, and stimulation of vascular smooth muscle cell proliferation [50-53].

Unique to Lp(a), studies suggest a role in the fibrinolytic system, based on the homology of the apo(a) protein with plasminogen. The normal conversion of plasminogen to plasmin is an important step in fibrinolysis. $\mathrm{Lp}(\mathrm{a})$ can inhibit plasmin formation in vitro, suggesting a potential antifibrinolytic role $[54,55]$. Further, $\operatorname{Lp}(\mathrm{a})$ can also increase the activity of plasminogen activator inhibitor in vitro [56]. Taken together, these studies highlight the contributions of $\mathrm{Lp}(\mathrm{a})$ to atherogenesis in a similar manner to LDL, as well as its unique proposed antifibrinolytic properties.

\section{Cardiovascular Risk Associated with Elevated Lp(a)}

The link between Lp(a) and CVD risk is not as established as LDL cholesterol; however, there is strong evidence that $L p(a)$ levels are a significant baseline risk factor. Assessment of Scandinavian Simvastatin Study patients revealed that subjects with major cardiovascular events had higher levels of $\mathrm{Lp}(\mathrm{a})$, which was also a predictor of mortality [17]. Other studies have demonstrated that $\operatorname{Lp}(\mathrm{a})$ is a significant risk factor in patients with previously existing CVD [57-59]. In 2014, a study by Khera et al. [60] found that $\operatorname{Lp}(\mathrm{a})$ levels were a determinant of residual risk in patients who had undergone statin therapy. Of note, $\mathrm{Lp}$ (a) levels are also an independent risk factor in $\mathrm{FH}$, and levels are shown to be higher in those with $\mathrm{FH}[61]$.

There appears to be a cumulative effect in which the combination of elevated LDL and Lp(a) levels increases the overall risk. The Prospective Cardiovascular Münster study followed 788 male participants for 10 years, measuring baseline risk factors including Lp(a) levels, LDL and HDL cholesterol, and triglycerides [62]. Lp(a) was shown to be an independent risk factor, increasing the risk of a coronary event by 2.7 times if serum $\mathrm{Lp}$ (a) was $>0.2 \mathrm{~g} / \mathrm{L}$.

$\mathrm{Lp}$ (a) levels remain a significant risk factor in patients who have received therapeutic intervention for their coronary heart disease [63]. One study assessed longterm (15 year) cardiovascular outcomes in patients who had undergone coronary artery bypass grafting, and indicated $\mathrm{Lp}(\mathrm{a})$ levels were an independent risk factor, causing a 3-fold increase in risk of major cardiovascular events [64]. Lastly, Lp(a) levels are implicated in noncoronary types of CVD, including stroke [65], peripheral arteriosclerosis [66] and aortic valve stenosis [67, 68].

\section{Current Standard of Care for Elevated LDL and Lp(a) Levels}

According to the 2013 AHA/American College of Cardiology guidelines, the current approach to elevated blood LDL-cholesterol begins with lifestyle modifications, including proper diet, regular exercise, and smoking cessation [69]. Statin therapy remains the first-line drug treatment for elevated LDL level and is indicated in both primary and secondary prevention of CVD [70]. There are currently no therapeutic targets for LDL levels recommended by the American College of Cardiology/ AHA; rather, statin dosing is guided by the patient's individual risk level. High-intensity statin therapy can result in LDL reduction of $>50 \%$, while moderate-intensity statin therapy typically results in $30-50 \%$ reduction. Statins are relatively safe; side effects are uncommon and generally muscle related [71].

If patients are intolerant or unresponsive to statin therapy, adjunct therapies may be added. Generally, ezetimibe, which acts to decrease cholesterol absorption in 
the small-intestine, is the first choice for adjunct therapy and has additional benefit combined with statin therapy $[72,73]$. Alternative adjunct therapies include bile acidbinding resins (colesevelam, colestipol) and niacin [74, 75]. A recent development is proprotein convertase subtilisin/kexin type 9 (PCSK9) inhibitors (alirocumab and evolocumab), human monoclonal antibodies that increase LDL receptor density by inhibiting binding of PCSK9 to the LDL receptor [76, 77]. Patients with homozygous $\mathrm{FH}$ do not respond as well to statins due to severely elevated LDL levels and require high-intensity dosing regimens [78] and adjunct therapy [76, 79]. Additional adjunct therapies used primarily for $\mathrm{FH}$, mipomersen, and lomitapide have significant hepatotoxicity [80]. For these patients, LA is a beneficial and often necessary intervention.

Unlike LDL, statins are largely ineffective in reducing $\mathrm{Lp}$ (a) levels [25]. To treat Lp(a) hyperlipoproteinemia, high-dose niacin can reduce $L p(a)$ levels by $20-40 \%$ [ 81 , 82]. PCSK9 inhibitors can also improve Lp(a) levels, although not as effectively as their action on LDL. Data from recent clinical trials with alirocumab [77] and evolocumab [83] demonstrated reduction of $\operatorname{Lp}(\mathrm{a})$ by 20 $30 \%$.

\section{Lipoprotein Apheresis in Cardiovascular Disease}

LA was first introduced as a treatment option for homozygous FH in the mid 1970s. A paper in France published in 1967 outlined the use of experimental plasmapheresis to reduce manifestations of FH [84]. Following this, Dr. Thompson et al. [85] in London, England, treated his patients suffering from $\mathrm{FH}$ with the experimental technique (Thompson et al. [85]). Dr. Lupien et al. [86], a Canadian physician, developed a manual heparin-based protocol that effectively reduced LDL levels in his patients. From the 1970s until present day, several different LA techniques have been developed.

LA is capable of removing both LDL and $\mathrm{Lp}(\mathrm{a})$ from the blood [87]. In FH, a single treatment of LA can reduce LDL by $65-70 \%$. LA for elevated LDL levels has FDA approval in the following situations: patients with homozygous $\mathrm{FH}$ with $>500 \mathrm{mg} / \mathrm{dL}$ LDL, heterozygous $\mathrm{FH}$ with no known CVD and $>300 \mathrm{mg} / \mathrm{dL} \mathrm{LDL}$, or with known CVD and LDL $>200 \mathrm{mg} / \mathrm{dL}$ [70]. It is recommended that LA begin in early childhood (ages 6-7) for homozygous $\mathrm{FH}$ patients to reduce the risk of CVD, particularly aortic valve stenosis [82]. In North America, LA is not the standard treatment option in patients with non-FH related hypercholesterolemia. However, guidelines vary by country. Germany has LA indications for LDL $120-130 \mathrm{mg} / \mathrm{dL}$ and progressive CVD, or isolated $\mathrm{Lp}(\mathrm{a})$-hyperlipoproteinemia ( $>60 \mathrm{mg} / \mathrm{dL}$ ) and progressive CVD. Japan has approved LA use in patients with CAD and total cholesterol $>250 \mathrm{mg} / \mathrm{dL}$ [88].

Further, LA is effective in reducing $\operatorname{Lp}(a)$ in situations of Lp(a)-hyperlipoproteinemia with subsequent reduction of CVD risk and can be beneficial in patients who are receiving maximal medication doses [89]. LA can reduce Lp(a) by $40-88 \%$ [82]. The American Society for Apheresis recommends the use of LA in Lp(a)-hyperlipoproteinemia. However, treatment is limited in the United States due to the scarcity of the centers offering LA, as well as the high cost [88].

The benefit of LA has also been suggested in several other medical conditions. Notably, LA in nephrotic syndrome can improve proteinuria and lipid levels, preventing the progression of renal disease [90-92]. LA has also been utilized in sudden sensorineural hearing loss [93], diabetic foot ulcers [94], and peripheral artery disease [95]. In addition to reduction of lipid levels, LA therapy also reduces inflammatory markers (including C-reactive protein and cellular adhesion molecules) [96-101] and circulating coagulation proteins (including fibrinogen and tissue factor) $[102,103]$. A protective role for LA therapy in reducing oxidative burden has been demonstrated $[104,105]$.

\section{LA Techniques}

Early lipid apheresis techniques utilized plasmapheresis principles to filter lipids out of plasma $[84,85]$. This nonspecific method required a filter with a defined pore size that effectively removed larger particles including LDL from plasma. A semi-selective process was later introduced that involved the use of a second filtration membrane (known as membrane differential filtration, double filtration) [106], but was still less specific than other targeted LA techniques.

\section{Immunoadsorption}

Heparin anticoagulation is indicated for this method. Blood is collected via vascular access and plasma is isolated. Plasma is filtered through 1 of 2 twin columns containing purified sheep antibodies that bind to ApoB- 100 . The antibodies are covalently linked to sepharose particles on the columns. Plasma flow alternates between columns; while one column is acting as the adsorption col- 
umn, the other column is regenerating. Regeneration occurs using a glycine buffer solution followed by a saline wash. Columns are regenerated and stored in sterile conditions, then can be reused for later apheresis sessions [107]. This treatment can reduce LDL and Lp(a) levels by approximately $55 \%$ [90].

\section{Dextran Sulfate Cellulose Absorption}

The Liposorber LA-15 system was approved by the FDA in 1996 for indications of LDL hypercholesterolemia [108]. Heparin use is indicated to prevent extracorporeal clotting. Vascular access is achieved and blood is segregated, isolating the plasma component. Plasma flows through 1 of 2 dextran sulfate cellulose (Liposorber) $150 \mathrm{~mL}$ columns, during which time binding of dextran sulfate to ApoB-100 protein captures ApoB-100 bound proteins including LDL, VLDL, and $\operatorname{Lp}(\mathrm{a})$. Flow is alternated between columns, allowing for each to regenerate before returning plasma flow to the area. Plasma and red blood cells are pooled and the patient is reinfused [109]. LDL levels can be decreased up to $76-81 \%$, and $L p(a)$ levels from 65 to $70 \%$ [110].

The Liposorber D uses a whole-blood technique in which plasma is not isolated prior to flow through the adsorption column [111]. The column contains negatively-charged dextran sulfate cellulose beads that can bind to ApoB-100 molecules (including LDL, VLDL, and Lp[a]). This method reduced LDL and Lp(a) by 62.2 and $55.6 \%$, respectively, with a single LA treatment [111].

\section{Heparin Extracorporeal LDL Precipitation}

This method is similar to the Liposorber technique, but heparin is used as a binding agent to ApoB-100 [112]. Plasma is isolated, treated with a heparin buffer solution at a $\mathrm{pH}$ of 4.85 , causing lipoprotein precipitation with fibrinogen and heparin. The LDL precipitate is filtered from the plasma, and excess heparin is adsorbed via filtration columns. Bicarbonate buffer dialysis is done to neutralize the $\mathrm{pH}$ of the plasma, before pooling with the red blood cell component and reinfusion of the patient [113, 114]. This method can reduce LDL and Lp(a) by $60 \%$ in a single session $[115,116]$. Further, it can also increase HDL over baseline levels in the long term (12-month follow-up) [116].

\section{Direct Adsorption of Lipoprotein Using \\ Hemoperfusion}

Heparin anticoagulation is indicated for this treatment [117]. The Direct Adsorption of Lipoprotein method uti- lizes a negatively charged matrix of polyacrylate bound to polyacrylamide beads. Whole blood is perfused through the absorption matrix, which can effectively bind LDL, VLDL, triglycerides, and Lp(a), while HDL is not affected. The pores of the beads are sufficiently small to avoid immobilization of red blood cells. The lipoproteins are eliminated, and the whole blood is reperfused back into the patient. This treatment is relatively simple and effective, reducing LDL and $\mathrm{Lp}(\mathrm{a})$ by over $60 \%$ per session $[107$, 118].

\section{Specific Lp(a) Apheresis}

There is currently only one Russian device on the market that can specifically remove $\mathrm{Lp}(\mathrm{a})$ from the blood [119]. In a similar manner to immunoadsorption, this method uses 2 sepharose columns bound to anti-Lp(a) monospecific polyclonal sheep antibodies. These columns can be regenerated for the patient in future treatments. This treatment has been shown to reduce $L p(a)$ levels by up $88 \%$, with unchanged LDL levels $[119,120]$.

\section{Effect of LDL Apheresis on CVD Outcomes}

Select studies assessing the effect of LA on cardiovascular outcomes are summarized in Table 1 . Studies of LA effect on other outcomes (atherosclerosis, carotid artery stenosis, peripheral artery disease) are discussed below but not included in Table 1. A prospective, observational multicenter study published by the Pro(a)LiFe study group in Germany assessed the impact of chronic LA in 170 patients receiving therapy for $\mathrm{Lp}(\mathrm{a})$-hyperlipoproteinemia and progressive CVD [121]. The initial study was published 2 years post commencement of LA therapy. Incidence rates of cardiovascular events, 2 years prior to commencing LA and 2 years post were compared. Average annual rates for adverse cardiovascular events (ACVE) decreased from 0.41 in the 2 years prior to LA, to 0.092 years after starting LA therapy. The first year of LA therapy resulted in 0.14 decline in ACVE, followed by 0.05 decline in the second year of therapy. In 2017, a follow-up study was published with the same cohort of patients, 5 years after starting LA therapy [122]. A total of $154(90.6 \%)$ patients completed follow-up to 5 years, where incidence of ACVE declined to a mean of 0.06 .

Several other retrospective studies indicated a link between LA and improved cardiovascular outcomes, in patients with elevated $\mathrm{Lp}(\mathrm{a})$ levels. A retrospective analysis of 37 patients receiving weekly LA treatments resulted in a reduction of $L p(a)$ levels by $68 \%$. Cardiovascular event-free 


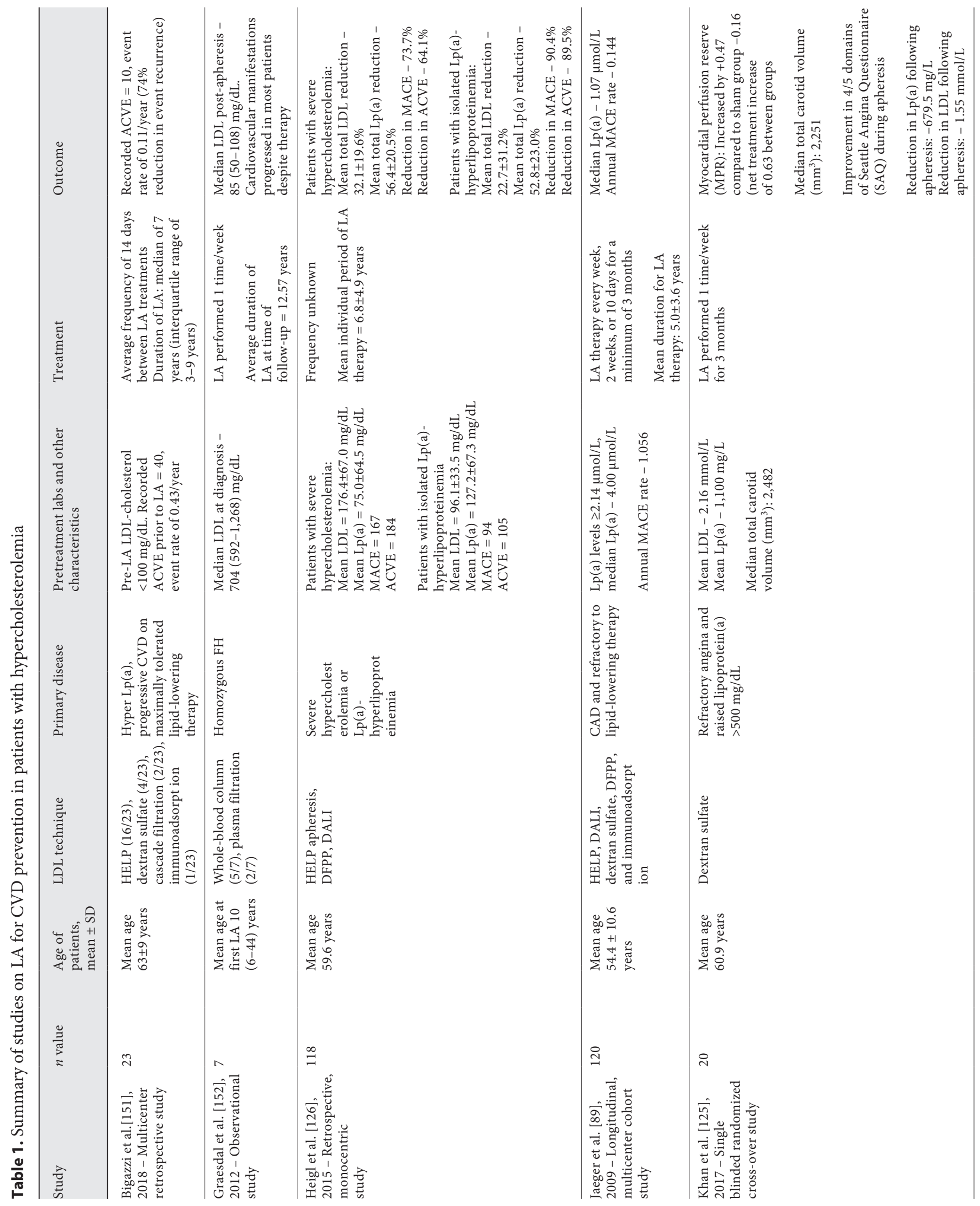



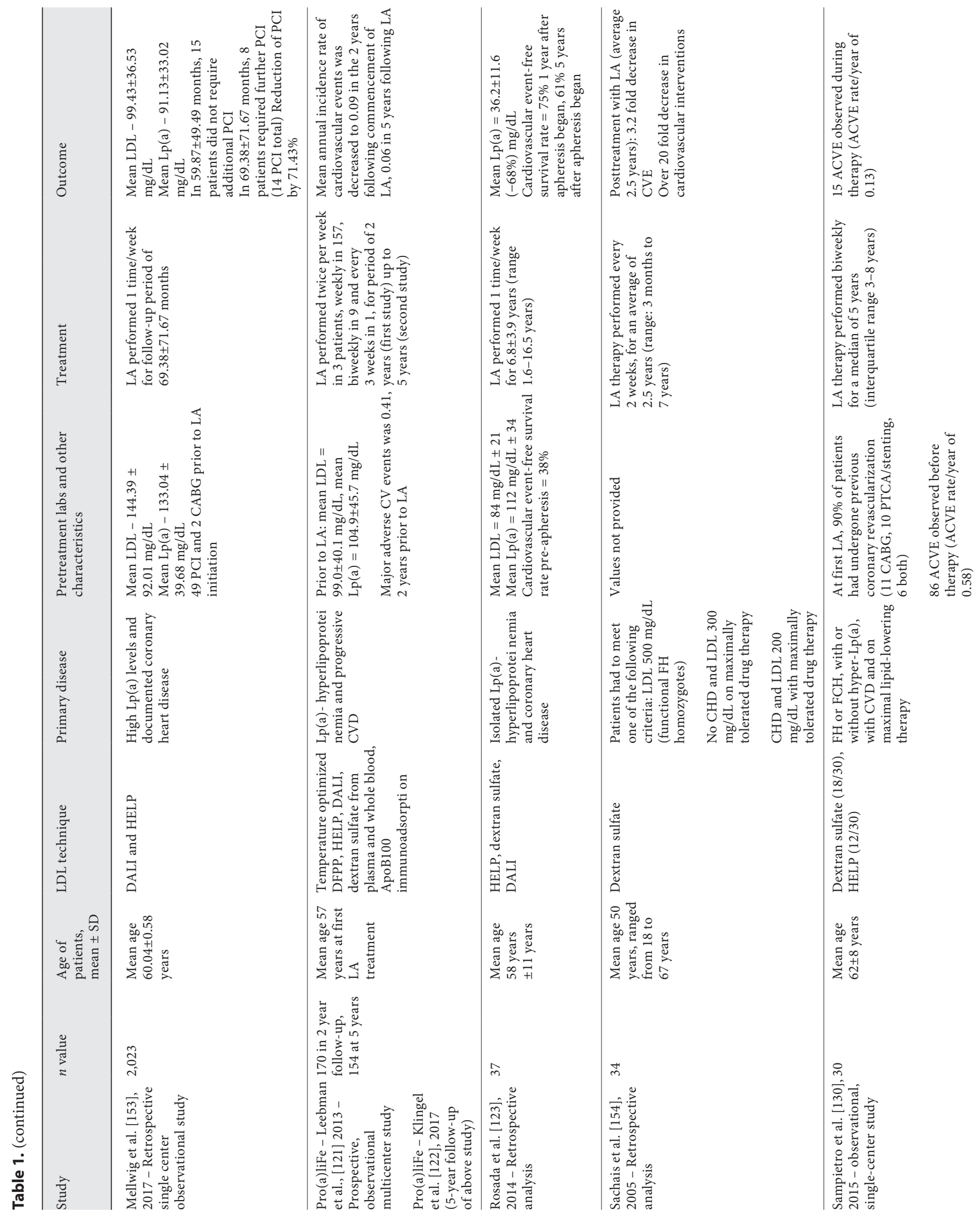


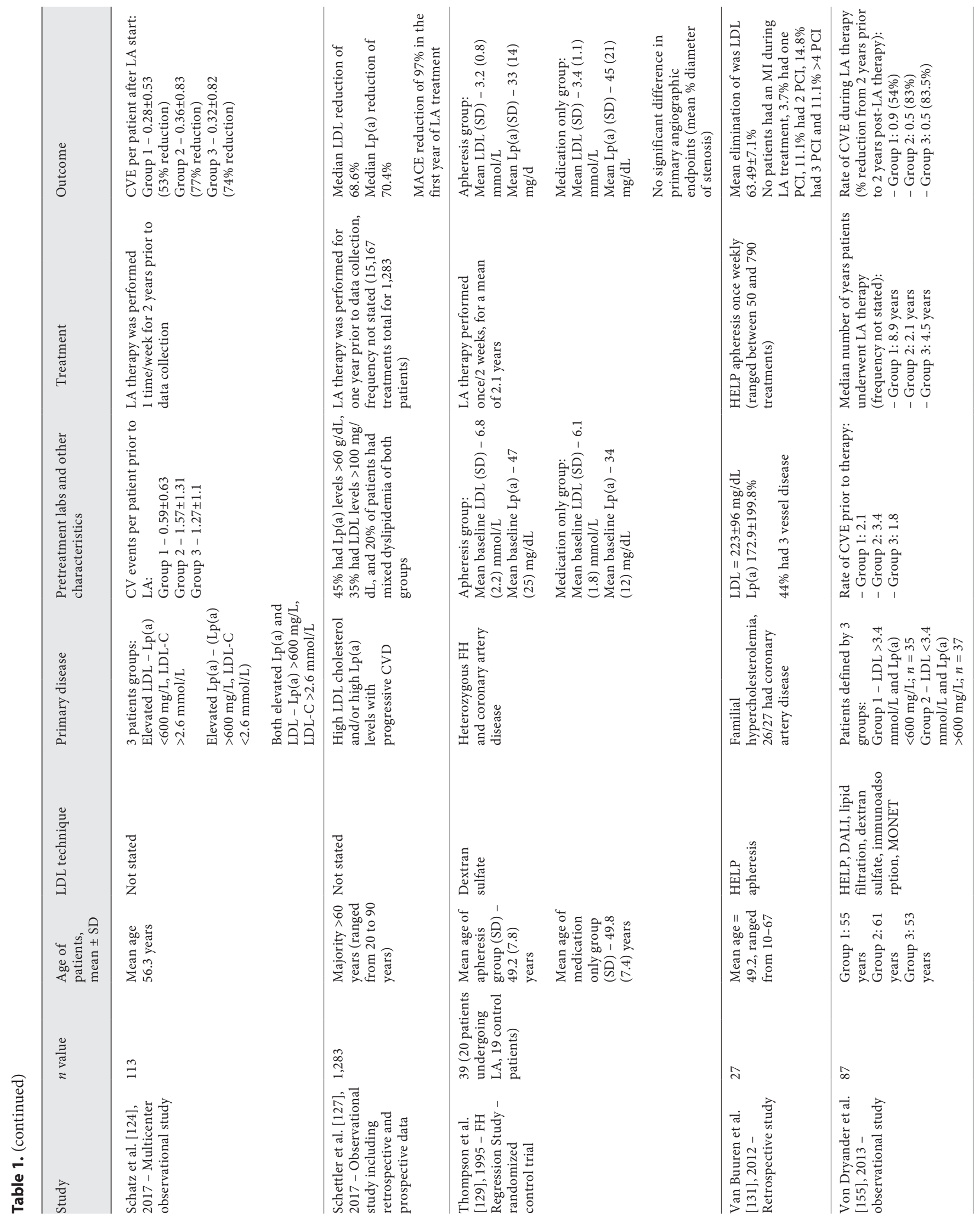




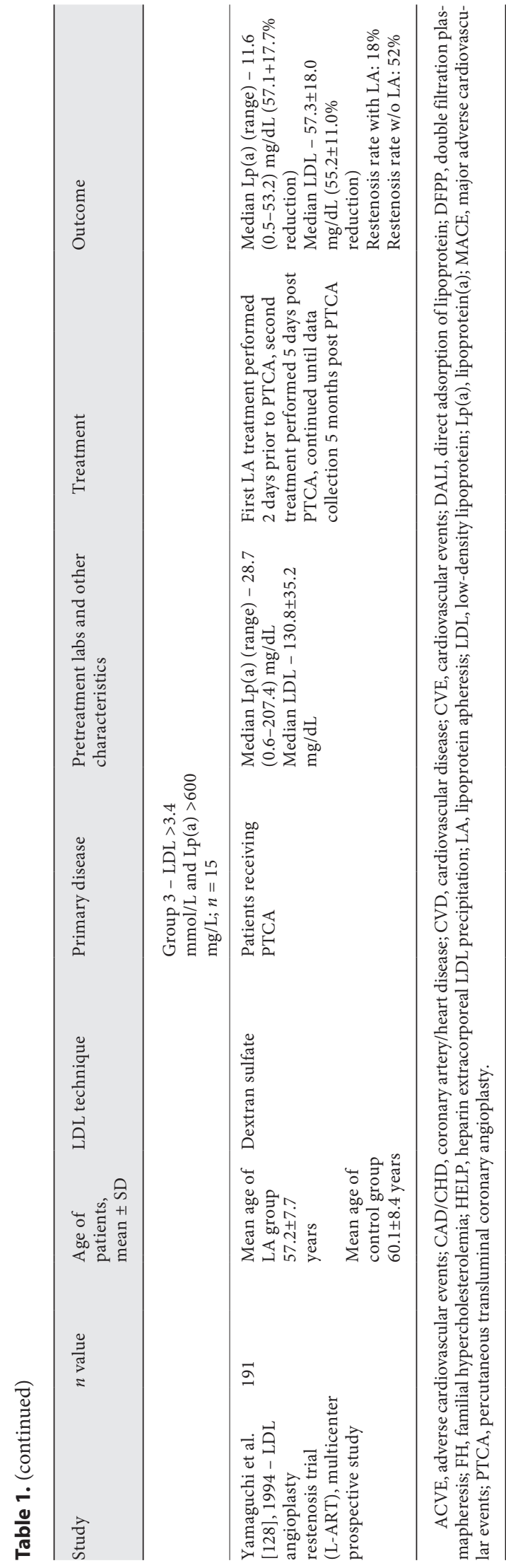

LA in CVD Risk Reduction survival rate increased from 38 to $75 \%, 1$ year after LA therapy began [123]. In 2009, Jaeger et al. [89] demonstrated similar results; LA apheresis lowered mean Lp(a) levels in 120 patients and reduced the rate of major ACVE from $1.056 /$ year to 0.144 /year. Last, in 2017, Schatz et al. [124] performed a multicenter observational study, in which they stratified 113 patients into groups dependent on LDL and Lp(a) levels; Group A had elevated LDL, Group B had elevated $\mathrm{Lp}(\mathrm{a})$, and Group $\mathrm{C}$ had both. They demonstrated that Group B (elevated Lp[a]) had the highest rate of ACVE prior to LA therapy and also had the greatest benefit from LA therapy (77\% reduction in ACVE). In a rare cross-over study, Khan et al. [125] assigned 20 patients with refractory angina and elevated $L p(a)$ to 3 months of LA therapy or 3 months sham, then groups received the alternate treatment for another 3-month period. Results showed a reduction in LDL and Lp(a) levels, as well as increased myocardial perfusion reserve $(+0.47)$ in the LA group compared to the sham group (decreased -0.16).

Additional studies on LA efficacy were observed in patients with LDL elevation, with or without Lp(a) elevation. In 2015, Heigl et al. [126] completed a retrospective analysis of 118 patients with severe hypercholesterolemia or isolated $\mathrm{Lp}(\mathrm{a})$-hyperlipoproteinemia over the course of several years (36,745 treatments). They demonstrated a reduction in LDL and Lp(a) levels in both groups, as well as a reduction in major ACVE of 73.7 and $64.1 \%$ for severe hypercholesterolemia and isolated $\mathrm{Lp}(\mathrm{a})$-hyperlipoproteinemia groups, respectively. Further, an observational study based on the German LA Registry assessed 1,283 patients with hypercholesterolemia and/or Lp(a)hyperlipoproteinemia over the period of 15,167 treatments, across multiple centers [127]. They concluded LA caused a reduction in $\mathrm{LDL}$ of $68.6 \%$ and $\mathrm{Lp}$ (a) $70.4 \%$. Importantly, major ACVEs were reduced by $97 \%$ in the first year following initiation of LA therapy. In 1994, Yamaguchi et al. [128] observed the effectiveness of LA in patients receiving PCI (previously termed PTCA), comparing a group of patients who received LA once prior to, and multiple times after their PCI, to a group of patients who did not receive LA. They demonstrated that the restenosis rate following LA (18\%) was significantly lower than the restenosis rate without LA (52\%).

A subset of studies focused primarily on patients with FH. Thompson et al. [129], published the FH Regression Study, in which they assessed 20 patients with FH undergoing dextran sulfate LA, compared to $19 \mathrm{FH}$ patients who were relying on medication. Although the apheresis group showed marked reduction in both LDL and Lp(a) levels, the progression of atherosclerosis (followed angio- 
graphically) was not significantly different between groups. However, other studies have indicated a link between LA and improved CVD in FH patients. Sampietro et al. [130] in 2015 assessed 30 patients with $\mathrm{FH}$ or FCH and observed an ACVE rate of 0.58/year prior to LA therapy, with an ACVE rate of 0.13/year following LA. A retrospective analysis of 27 patients with $\mathrm{FH}$ who received 8,533 Heparin Extracorporeal LDL Precipitation (HELP) apheresis treatments, with an average follow-up period of $7.0 \pm 5.2$ years, indicated that LA was successful in reducing LDL levels (average reduction of $63.49 \pm 7.1 \%$ ) and produced low levels of coronary intervention [131].

\section{Effect of LDL Apheresis on Atherosclerosis}

The HELP-Study Group published one of the first systematic evidence that HELP apheresis was beneficial in CVD [116]. Thirty nine patients received regular HELP apheresis for 2 years and demonstrated a decrease in the mean degree of stenosis measured angiographically from 32.5 to $30.6 \%$. The LDL-Apheresis Regression study group in Japan assessed changes in coronary artery stenosis angiographically in 37 patients with familial hypercholesterolemia (FH; $n=32$ ) or nongenetic hypercholesterolemia $(n=5)$ [132]. They demonstrated that regression of stenosis occurred in 14 patients following $>1$ year of LA therapy. A similar group in the Netherlands did a 2 year study of 42 men with hypercholesterolemia and progressive CAD [133]. Twenty one men received bi-weekly LA therapy and simvastatin, while a control group received simvastatin alone. LDL reduction was observed in both groups, to a greater extent in the LA therapy group. In 2013, Safarova et al. [134] examined the effects of Lp(a) apheresis therapy on coronary artery atherosclerosis regression, compared to statin therapy alone. Mean diameter stenosis was reduced by -2.0 with LA, while it increased by 3.5 in the statin only group. In 2009, Stefanutti et al. [135] assessed the impact of LA specifically in children with FH $(n=11)$ and concluded that LA resulted in the regression of coronary artery stenosis, and coronary intervention was not required in any patient (patients were evaluated from 2 to 17 years).

\section{Effect of LA on Carotid Artery Stenosis and Peripheral Artery Disease}

In 1999, Koga et al. [136] published a study examining the long-term effect of LA on carotid artery atherosclerosis. Eleven FH patients received LA for an average of
7.8 years, while 10 control $\mathrm{FH}$ patients received medication only for an average of 5.5 years. LDL levels were reduced significantly with LA, although new plaque formation in the carotid arteries was observed in both groups. However, annual progression rate was slower in the LA group $(-0.0023 \pm 0.0246 \mathrm{~mm} /$ year $)$ compared to the control group ( $0.0251 \pm 0.0265 \mathrm{~mm} /$ year). Kroon et al. [137] compared the effects of LA therapy versus statins on the progression of peripheral artery disease, in 42 men with hypercholesterolemia. They demonstrated a reduction in stenosis of the aortotibial tract, as well as a decrease in carotid intima-media thickness in the LA group, while the statin group increased in both aspects. A 2015 study evaluated shear stress on the carotid artery walls during LA therapy in 52 procedures [138]. They demonstrated an initial increase in shear stress, potentially due to the procedure itself, followed by an improvement in shear stress. Lastly, Ezhov et al. [139] demonstrated the benefit of $\operatorname{Lp}(\mathrm{a})$-specific apheresis therapy in 30 patients with CHD. At 9 and 18 months following initiation of LA, changes in carotid intima-media thickness were $-0.03 \pm$ 0.09 and $-0.07 \pm 0.15 \mathrm{~mm}$, respectively, with no significant changes in the control group.

Multiple studies have examined the effects of LA therapy on hemodialysis patients with peripheral artery occlusive disease. Eleven patients underwent 10 sessions of LA and demonstrated corresponding reduction in LDL levels, as well as an increase in endothelium-dependent vasodilation (from $1.6 \pm 0.6$ to $4.7 \pm 1.0 \%$ ) [140]. In 2 independent case studies in which patients developed intractable ulcers in their feet due to peripheral artery occlusion, LA therapy promoted healing of the wound $[141,142]$.

\section{Adverse Effects and Precautions for LDL Apheresis}

The LA procedure is generally very well-tolerated in the acute and long term, with minimal side effects. A common transient symptom in patients is feeling tension in the legs, potentially in the hands and eyelids as well [143]. Side effects occur in approximately $5.5 \%$ of patients and do not appear to differ between LA methods [144]. Vaso-vagal reactions are the most common, presenting as malaise, weakness, or transient hypotension [143]. There is a small risk of hypotension, which can occur in approximately $<1 \%$ of patients [144]. Notably, some LA machines can result in significant removal of B12, transferrin, and ferritin causing anemia and may require iron supplementation [145]. One study evaluated 29 patients receiving regular LA to determine impact on their quality 
of life (QOL) [146]. Results indicated that patients felt their physical QOL was similar to those of the general population; however, their mental and emotional QOL rated below the general population. It is unknown if the repetitive LA procedure itself can cause emotional or mental distress for patients, or if other factors are causative. There are relatively few contraindications to LA therapy. However, the use of angiotensin-converting enzyme inhibitors are contraindicated [147]. The adsorption process can promote bradykinin release due to the negative charge of the adsorption surface, creating a potential risk for bradykinin syndrome, including hypotension, dyspnea, and shock [148]. Angiotensin II receptor blockers may be used as a substitute medication for blood pressure control, or angiotensin-converting enzyme inhibitor medication may be held for $24 \mathrm{~h}$ prior to treatment.

\section{Limitations and Future Directions}

The studies discussed above demonstrate a clear benefit for LA therapy in the management of LDL hypercholesterolemia and/or isolated Lp(a)-hyperlipoproteinemia, in the prevention and progression of CVD. However, the majority of studies are observational (either retrospective or prospective). It is difficult to achieve ethical approval for RCTs assessing LA. However, a clinical trial currently underway (MultiSELECt - A European Multicenter Study on the effect of Lipoprotein(a) elimination by LA on cardiovascular outcomes) has circumvented this barrier by designing a study in which patients who receive LA in Germany are compared with matched patients elsewhere in Europe, in countries who do not offer reimbursed LA therapy [149]. Future studies such as these may provide stronger evidence for a role of LA therapy in the management of dyslipidemia and CVD.

Current FDA guidelines approve LA primarily for use in $\mathrm{FH}$, and it is not a standard of care in the majority of patients with dyslipidemia in the United States. Countries including Germany and Japan are more advanced in terms of funding and availability of LA therapy, for patient populations outside of the FH subset. Obstacles include the time, cost, and difficulty some patients face accessing lipid apheresis centers in the United States. The development of new lipid-lowering therapy, particularly PCSK9 inhibitors including evolocumab, has caused debate as to whether these medications may be sufficient on their own to lower cholesterol levels and CVD risk. In 2017, a study by Hohenstein et al. [150] suggested that only a small subset (10-12\%) of patients receiving LA for elevated LDL in Germany may be able to stop LA and rely solely on PSCK9 inhibitors. Further studies are required to fully compare PCSK9 inhibitors to the efficacy of LA therapy. Of note, the additional benefits of LA therapy, aside from reduction of LDL and $L p(a)$ levels, are not present to the same extent with lipid-lowering therapy alone, and this should be considered when choosing a treatment option for a patient with hypercholesterolemia.

\section{Conclusion}

It is well established that elevated levels of LDL and/or $\mathrm{Lp}(\mathrm{a})$ are atherogenic and can promote the development and progression of CVD. Current therapies include firstline statin treatment, as well as adjunct therapies including ezetimibe and PCSK9 inhibitors. LA therapy is an additional treatment option to reduce cholesterol levels and remains a standard of care for patients with FH. The studies reviewed here indicate a beneficial role for LA therapy in the reduction of LDL and $\mathrm{Lp}(\mathrm{a})$ levels, as well as the reduction in ACVEs. Additional RCTs are required to strengthen the association between LA and CVD prevention. However, based on current evidence, LA therapy may be considered a safe, effective option for patients with hypercholesterolemia who are not responsive to standard lipid-lowering medication.

\section{Disclosure Statement}

Authors have no conflict of interest to declare.

\section{Funding Source}

This research received no specific grant from any funding agency in the public, commercial, or not-for-profit sectors.
References
1 Benjamin EJ, Virani SS, Callaway CW, Chamberlain AM, Chang AR, Cheng S, et al.; American Heart Association Council on Epi- demiology and Prevention Statistics Com- mittee and Stroke Statistics Subcommittee. Heart Disease and Stroke Statistics-2018 Up- date: A Report From the American Heart As- sociation. Circulation. 2018 Mar; 137(12): e67-492.
2 Fryar CD, Chen TC, Li X. Prevalence of un- controlled risk factors for cardiovascular dis- ease: United States, 1999-2010. NCHS Data Brief. 2012 Aug;(103):1-8. 
3 Brown MS, Goldstein JL. Familial hypercholesterolemia: defective binding of lipoproteins to cultured fibroblasts associated with impaired regulation of 3-hydroxy3-methylglutaryl coenzyme A reductase activity. Proc Natl Acad Sci USA. 1974 Mar; 71(3):788-92.

4 Stamler J, Vaccaro O, Neaton JD, Wentworth D. Diabetes, other risk factors, and 12-yr cardiovascular mortality for men screened in the Multiple Risk Factor Intervention Trial. Diabetes Care. 1993 Feb;16(2):434-44.

5 Chen Z, Peto R, Collins R, MacMahon S, Lu J, Li W. Serum cholesterol concentration and coronary heart disease in population with low cholesterol concentrations. BMJ. 1991 Aug; 303(6797):276-82.

6 Lunin VY, Lunina NL, Ritter S, Frey I, Berg A, Diederichs K, et al. Low-resolution data analysis for low-density lipoprotein particle. Acta Crystallogr D Biol Crystallogr. 2001 Jan;57(Pt 1):108-21.

7 Laggner P, Degovics G, Müller KW, Glatter O, Kratky O, Kostner G, et al. Molecular packing and fluidity of lipids in human serum low density lipoproteins. Hoppe Seylers Z Physiol Chem. 1977 Jul;358(7):771-8.

8 Jeon H, Blacklow SC. Structure and physiologic function of the low-density lipoprotein receptor. Annu Rev Biochem. 2005;74(1): $535-62$.

9 Krauss RM. Dense low density lipoproteins and coronary artery disease. Am J Cardiol. 1995 Feb;75(6):53B-7B.

10 McNamara JR, Campos H, Ordovas JM, Peterson J, Wilson PW, Schaefer EJ. Effect of gender, age, and lipid status on low density lipoprotein subfraction distribution. Results from the Framingham Offspring Study. Arteriosclerosis. 1987 Sep-Oct;7(5):483-90.

11 Williams PT, Superko HR, Haskell WL, Alderman EL, Blanche PJ, Holl LG, et al. Smallest LDL particles are most strongly related to coronary disease progression in men. Arterioscler Thromb Vasc Biol. 2003 Feb;23(2): $314-21$.

12 Kathiresan S, Otvos JD, Sullivan LM, Keyes MJ, Schaefer EJ, Wilson PW, et al. Increased small low-density lipoprotein particle number: a prominent feature of the metabolic syndrome in the Framingham Heart Study. Circulation. 2006 Jan;113(1):20-9.

13 Srisawasdi P, Vanavanan S, Rochanawutanon M, Kruthkul K, Kotani K, Kroll MH. Smalldense LDL/large-buoyant LDL ratio associates with the metabolic syndrome. Clin Biochem. 2015 May;48(7-8):495-502.

14 Jang EH, Park YM, Hur J, Kim MK, Ko SH, Baek KH, et al. Higher levels of small dense low-density lipoprotein (LDL) are associated with cardiac autonomic neuropathy in patients with type 2 diabetes. Diabet Med. 2013 Jun;30(6):694-701.

15 Soutar AK, Naoumova RP. Mechanisms of disease: genetic causes of familial hypercholesterolemia. Nat Clin Pract Cardiovasc Med. 2007 Apr;4(4):214-25.
16 Tolleshaug H, Goldstein JL, Schneider WJ, Brown MS. Posttranslational processing of the LDL receptor and its genetic disruption in familial hypercholesterolemia. Cell. 1982 Oct; 30(3):715-24

17 Berg K, Dahlén G, Christophersen B, Cook T, Kjekshus J, Pedersen T. Lp(a) lipoprotein level predicts survival and major coronary events in the Scandinavian Simvastatin Survival Study. Clin Genet. 1997 Nov;52(5):25461.

18 Kamstrup PR, Benn M, Tybjaerg-Hansen A, Nordestgaard BG. Extreme lipoprotein(a) levels and risk of myocardial infarction in the general population: the Copenhagen City Heart Study. Circulation. 2008 Jan;117(2): 176-84.

19 Gaubatz JW, Chari MV, Nava ML, Guyton JR, Morrisett JD. Isolation and characterization of the two major apoproteins in human lipoprotein [a]. J Lipid Res. 1987 Jan;28(1):69-79.

20 McLean JW, Tomlinson JE, Kuang WJ, Eaton DL, Chen EY, Fless GM, et al. cDNA sequence of human apolipoprotein(a) is homologous to plasminogen. Nature. 1987 Nov;330(6144): 132-7.

21 Mack S, Coassin S, Rueedi R, Yousri NA, Seppälä I, Gieger C, et al.; KORA-Study Group. A genome-wide association meta-analysis on lipoprotein (a) concentrations adjusted for apolipoprotein (a) isoforms. J Lipid Res. 2017 Sep;58(9):1834-44.

22 Clarke R, Peden JF, Hopewell JC, Kyriakou T, Goel A, Heath SC, et al.; PROCARDIS Consortium. Genetic variants associated with $\mathrm{Lp}$ (a) lipoprotein level and coronary disease. N Engl J Med. 2009 Dec;361(26):2518-28.

23 Argraves KM, Kozarsky KF, Fallon JT, Harpel PC, Strickland DK. The atherogenic lipoprotein $\mathrm{Lp}(\mathrm{a})$ is internalized and degraded in a process mediated by the VLDL receptor. J Clin Invest. 1997 Nov;100(9): 2170-81.

24 Haffner S, Orchard T, Stein E, Schmidt D, LaBelle P. Effect of simvastatin on Lp(a) concentrations. Clin Cardiol. 1995 May;18(5): 261-7.

25 Goudevenos JA, Bairaktari ET, Chatzidimou KG, Milionis HJ, Mikhailidis DP, Elisaf MS. The effect of atorvastatin on serum lipids, lipoprotein(a) and plasma fibrinogen levels in primary dyslipidaemia - a pilot study involving serial sampling. Curr Med Res Opin. 2001; 16(4):269-75.

26 McKenney JM, Jones PH, Bays HE, Knopp RH, Kashyap ML, Ruoff GE, et al. Comparative effects on lipid levels of combination therapy with a statin and extended-release niacin or ezetimibe versus a statin alone (the COMPELL study). Atherosclerosis. 2007 Jun; 192(2):432-7.

27 Williams KJ, Tabas I. The response-to-retention hypothesis of early atherogenesis. Arterioscler Thromb Vasc Biol. 1995 May;15(5): 551-61.

28 Fogelstrand P, Borén J. Retention of atherogenic lipoproteins in the artery wall and its role in atherogenesis. Nutr Metab Cardiovasc Dis. 2012 Jan;22(1):1-7.

29 Nakashima Y, Fujii H, Sumiyoshi S, Wight TN, Sueishi K. Early human atherosclerosis: accumulation of lipid and proteoglycans in intimal thickenings followed by macrophage infiltration. Arterioscler Thromb Vasc Biol. 2007 May;27(5):1159-65.

30 Brown MS, Goldstein JL. A receptor-mediated pathway for cholesterol homeostasis. Science. 1986 Apr 4;232(4746):34-47.

31 Mestas J, Ley K. Monocyte-endothelial cell interactions in the development of atherosclerosis. Trends Cardiovasc Med. 2008 Aug; 18(6):228-32.

32 Li AC, Glass CK. The macrophage foam cell as a target for therapeutic intervention. Nat Med. 2002 Nov;8(11):1235-42.

33 Huszar D, Varban ML, Rinninger F, Feeley R, Arai T, Fairchild-Huntress V, et al. Increased LDL cholesterol and atherosclerosis in LDL receptor-deficient mice with attenuated expression of scavenger receptor B1. Arterioscler Thromb Vasc Biol. 2000 Apr;20(4): 1068-73.

34 Akhmedov A, Rozenberg I, Paneni F, Camici GG, Shi Y, Doerries C, et al. Endothelial overexpression of LOX-1 increases plaque formation and promotes atherosclerosis in vivo. Eur Heart J. 2014 Oct;35(40): 2839-48.

35 Hsu HY, Chiu SL, Wen MH, Chen KY, Hua KF. Ligands of macrophage scavenger receptor induce cytokine expression via differential modulation of protein kinase signaling pathways. J Biol Chem. 2001 Aug;276(31):2871930.

36 Panousis CG, Zuckerman SH. Regulation of cholesterol distribution in macrophage-derived foam cells by interferon-gamma. J Lipid Res. 2000 Jan;41(1):75-83.

37 Watanabe T, Pakala R, Koba S, Katagiri T, Benedict CR. Lysophosphatidylcholine and reactive oxygen species mediate the synergistic effect of mildly oxidized LDL with serotonin on vascular smooth muscle cell proliferation. Circulation. 2001 Mar;103(10):14405.

38 Stiko A, Regnström J, Shah PK, Cercek B, Nilsson J. Active oxygen species and lysophosphatidylcholine are involved in oxidized low density lipoprotein activation of smooth muscle cell DNA synthesis. Arterioscler Thromb Vasc Biol. 1996 Feb;16(2): 194-200.

39 Gutstein DE, Fuster V. Pathophysiology and clinical significance of atherosclerotic plaque rupture. Cardiovasc Res. 1999 Feb;41(2):32333.

40 Lewington S, Whitlock G, Clarke R, Sherliker P, Emberson J, Halsey J, et al.; Prospective Studies Collaboration. Blood cholesterol and vascular mortality by age, sex, and blood pressure: a meta-analysis of individual data from 61 prospective studies with 55,000 vascular deaths. Lancet. 2007 Dec;370(9602): 1829-39. 
41 Ueba T, Nomura S, Nishikawa T, Kajiwara M, Yamashita K. Circulating oxidized LDL, measured with FOH1a/DLH3 antibody, is associated with metabolic syndrome and the coronary heart disease risk score in healthy Japanese. Atherosclerosis. 2009 Mar;203(1): 243-8.

42 Holvoet P, Harris TB, Tracy RP, Verhamme $\mathrm{P}$, Newman AB, Rubin SM, et al. Association of high coronary heart disease risk status with circulating oxidized LDL in the well-functioning elderly: findings from the Health, Aging, and Body Composition study. Arterioscler Thromb Vasc Biol. 2003 Aug;23(8): $1444-8$.

43 Pohjantähti-Maaroos H, Palomäki A, Kankkunen P, Husgafvel S, Knuth T, Vesterinen $\mathrm{K}$, et al. Arterial elasticity and oxidized LDL among men with metabolic syndrome and different 10-year cardiovascular risk estimated by FINRISK and SCORE models. Ann Med. 2012 Aug;44(5): 503-12.

44 Baigent C, Keech A, Kearney PM, Blackwell L, Buck G, Pollicino C, et al.; Cholesterol Treatment Trialists' (CTT) Collaborators. Efficacy and safety of cholesterol-lowering treatment: prospective meta-analysis of data from 90,056 participants in 14 randomised trials of statins. Lancet. 2005 Oct;366(9493): 1267-78.

45 Baigent C, Blackwell L, Emberson J, Holland LE, Reith C, Bhala N, et al.; Cholesterol Treatment Trialists' (CTT) Collaboration. Efficacy and safety of more intensive lowering of LDL cholesterol: a meta-analysis of data from 170,000 participants in 26 randomised trials. Lancet. 2010 Nov;376(9753): 1670-81.

46 Hobbs HH, Brown MS, Goldstein JL. Molecular genetics of the LDL receptor gene in familial hypercholesterolemia. Hum Mutat. 1992; 1(6):445-66.

47 Page MM, Bell DA, Hooper AJ, Watts GF, Burnett JR. Lipoprotein apheresis and new therapies for severe familial hypercholesterolemia in adults and children. Best Pract Res Clin Endocrinol Metab. 2014 Jun;28(3):387403.

48 Morishita R, Ishii J, Kusumi Y, Yamada S, Komai N, Ohishi M, et al. Association of serum oxidized lipoprotein(a) concentration with coronary artery disease: potential role of oxidized lipoprotein(a) in the vasucular wall. J Atheroscler Thromb. 2009 Aug; 16(4): $410-8$.

49 Umahara T, Uchihara T, Yamada S, Hashimoto T, Akimoto J, Haraoka J, et al. Differential expression of oxidized/native lipoprotein(a) and plasminogen in human carotid and cerebral artery plaques. Atherosclerosis. 2011 Apr;215(2):392-8.

50 Allen S, Khan S, Tam S, Koschinsky M, Taylor P, Yacoub M. Expression of adhesion molecules by $\operatorname{lp}(\mathrm{a})$ : a potential novel mechanism for its atherogenicity. FASEB J. 1998 Dec; 12(15):1765-76.
51 Zioncheck TF, Powell LM, Rice GC, Eaton DL, Lawn RM. Interaction of recombinant apolipoprotein(a) and lipoprotein(a) with macrophages. J Clin Invest. 1991 Mar;87(3): 767-71.

52 Komai N, Morishita R, Yamada S, Oishi M, Iguchi S, Aoki M, et al. Mitogenic activity of oxidized lipoprotein (a) on human vascular smooth muscle cells. Hypertension. 2002 Sep; 40(3):310-4.

53 Kojima S, Harpel PC, Rifkin DB. Lipoprotein (a) inhibits the generation of transforming growth factor beta: an endogenous inhibitor of smooth muscle cell migration. J Cell Biol. 1991 Jun;113(6):1439-45.

54 Knapp JP, Herrmann W. In vitro inhibition of fibrinolysis by apolipoprotein(a) and lipoprotein(a) is size- and concentration-dependent. Clin Chem Lab Med. 2004;42(9): 1013-9.

55 Romagnuolo R, Marcovina SM, Boffa MB, Koschinsky ML. Inhibition of plasminogen activation by apo(a): role of carboxyl-terminal lysines and identification of inhibitory domains in apo(a). J Lipid Res. 2014 Apr;55(4): 625-34.

56 Ren S, Man RY, Angel A, Shen GX. Oxidative modification enhances lipoprotein(a)-induced overproduction of plasminogen activator inhibitor-1 in cultured vascular endothelial cells. Atherosclerosis. 1997 Jan;128(1):1-10.

57 Maher VM, Brown BG, Marcovina SM, Hillger LA, Zhao XQ, Albers JJ. Effects of lowering elevated LDL cholesterol on the cardiovascular risk of lipoprotein(a). JAMA. 1995 Dec;274(22):1771-4.

58 O’Donoghue ML, Morrow DA, Tsimikas S, Sloan S, Ren AF, Hoffman EB, et al. Lipoprotein(a) for risk assessment in patients with established coronary artery disease. J Am Coll Cardiol. 2014 Feb;63(6):520-7.

59 Nestel PJ, Barnes EH, Tonkin AM, Simes J, Fournier M, White HD, et al. Plasma lipoprotein(a) concentration predicts future coronary and cardiovascular events in patients with stable coronary heart disease. Arterioscler Thromb Vasc Biol. 2013 Dec; 33(12):2902-8

60 Khera AV, Everett BM, Caulfield MP, Hantash FM, Wohlgemuth J, Ridker PM, et al. Lipoprotein(a) concentrations, rosuvastatin therapy, and residual vascular risk: an analysis from the JUPITER Trial (Justification for the Use of Statins in Prevention: an Intervention Trial Evaluating Rosuvastatin). Circulation. $2014 \mathrm{Feb} ; 129(6): 635-42$.

61 Alonso R, Andres E, Mata N, Fuentes-Jiménez F, Badimón L, López-Miranda J, et al.; SAFEHEART Investigators. Lipoprotein(a) levels in familial hypercholesterolemia: an important predictor of cardiovascular disease independent of the type of LDL receptor mutation. J Am Coll Cardiol. 2014 May;63(19): 1982-9.

62 von Eckardstein A, Schulte H, Cullen P, Assmann G. Lipoprotein(a) further increases the risk of coronary events in men with high glob- al cardiovascular risk. J Am Coll Cardiol. 2001 Feb;37(2):434-9.

63 Daida H, Lee YJ, Yokoi H, Kanoh T, Ishiwata S, Kato K, et al.; Low-Density Lipoprotein Apheresis Angioplasty Restenosis Trial (L-ART) Group. Prevention of restenosis after percutaneous transluminal coronary angioplasty by reducing lipoprotein (a) levels with low-density lipoprotein apheresis. Am J Cardiol. 1994 Jun;73(15): 1037-40.

64 Ezhov MV, Safarova MS, Afanasieva OI, Kukharchuk VV, Pokrovsky SN. Lipoprotein(a) level and apolipoprotein(a) phenotype as predictors of long-term cardiovascular outcomes after coronary artery bypass grafting. Atherosclerosis. 2014 Aug; 235(2):477-82

65 Erqou S, Kaptoge S, Perry PL, Di Angelantonio E, Thompson A, White IR, et al.; Emerging RiskFactors Collaboration.Lipoprotein(a) concentration and the risk of coronary heart disease, stroke, and nonvascular mortality. JAMA. 2009 Jul;302(4):412-23.

66 Laschkolnig A, Kollerits B, Lamina C, Meisinger C, Rantner B, Stadler M, et al. Lipoprotein (a) concentrations, apolipoprotein (a) phenotypes, and peripheral arterial disease in three independent cohorts. Cardiovasc Res. $2014 \mathrm{Jul} ; 103(1): 28-36$.

67 Kamstrup PR, Tybjærg-Hansen A, Nordestgaard BG. Elevated lipoprotein(a) and risk of aortic valve stenosis in the general population. J Am Coll Cardiol. 2014 Feb;63(5):470-7.

68 Thanassoulis G, Campbell CY, Owens DS, Smith JG, Smith AV, Peloso GM, et al.; CHARGE Extracoronary Calcium Working Group. Genetic associations with valvular calcification and aortic stenosis. N Engl J Med. 2013 Feb;368(6):503-12.

69 Eckel RH, Jakicic JM, Ard JD, de Jesus JM, Houston Miller N, Hubbard VS, et al.; American College of Cardiology/American Heart Association Task Force on Practice Guidelines. 2013 AHA/ACC guideline on lifestyle management to reduce cardiovascular risk: a report of the American College of Cardiology/American Heart Association Task Force on Practice Guidelines. J Am Coll Cardiol. 2014 Jul;63(25 25 Pt B):2960-84.

70 Stone NJ, Robinson JG, Lichtenstein AH, Bairey Merz CN, Blum CB, Eckel RH, et al.; American College of Cardiology/American Heart Association Task Force on Practice Guidelines. 2013 ACC/AHA guideline on the treatment of blood cholesterol to reduce atherosclerotic cardiovascular risk in adults: a report of the American College of Cardiology/ American Heart Association Task Force on Practice Guidelines. J Am Coll Cardiol. 2014 Jul;63(25 25 Pt B):2889-934.

71 Rosenson RS, Baker SK, Jacobson TA, Kopecky SL, Parker BA; The National Lipid Association's Muscle Safety Expert Panel. An assessment by the statin muscle safety task force: 2014 update. J Clin Lipidol. 2014 MayJun;8(3 Suppl):S58-71. 
72 Lloyd-Jones DM, Morris PB, Ballantyne CM, Birtcher KK, Daly DD Jr, DePalma SM, et al.; Writing Committee. 2016 ACC expert consensus decision pathway on the role of nonstatin therapies for LDL-cholesterol lowering in the management of atherosclerotic cardiovascular disease risk: A Report of the American College of Cardiology Task Force on Clinical Expert Consensus Documents. J Am Coll Cardiol. 2016 Jul;68(1):92-125.

73 Cannon CP, Blazing MA, Giugliano RP, McCagg A, White JA, Theroux P, et al.; IMPROVE-IT Investigators. Ezetimibe added to statin therapy after acute coronary syndromes. N Engl J Med. 2015 Jun;372(25):2387-97.

74 Gudzune KA, Monroe AK, Sharma R, Ranasinghe PD, Chelladurai Y, Robinson KA. Effectiveness of combination therapy with statin and another lipid-modifying agent compared with intensified statin monotherapy: a systematic review. Ann Intern Med. 2014 Apr;160(7):468-76.

75 Taylor AJ, Villines TC, Stanek EJ, Devine PJ, Griffen L, Miller M, et al. Extended-release niacin or ezetimibe and carotid intima-media thickness. N Engl J Med. 2009 Nov;361(22): 2113-22.

76 Raal FJ, Honarpour N, Blom DJ, Hovingh GK, Xu F, Scott R, et al.; TESLA Investigators. Inhibition of PCSK9 with evolocumab in homozygous familial hypercholesterolaemia (TESLA Part B): a randomised, double-blind, placebo-controlled trial. Lancet. 2015 Jan; 385(9965):341-50.

77 Gaudet D, Watts GF, Robinson JG, Minini P, Sasiela WJ, Edelberg J, et al. Effect of Alirocumab on Lipoprotein(a) over $\geq 1.5$ Years (from the Phase 3 ODYSSEY Program). Am J Cardiol. 2017 Jan;119(1):40-6.

78 Raal FJ, Pilcher GJ, Illingworth DR, Pappu AS, Stein EA, Laskarzewski P, et al. Expanded-dose simvastatin is effective in homozygous familial hypercholesterolaemia. Atherosclerosis. 1997 Dec;135(2):249-56.

79 Kastelein JJ, Akdim F, Stroes ES, Zwinderman AH, Bots ML, Stalenhoef AF, et al.; ENHANCE Investigators. Simvastatin with or without ezetimibe in familial hypercholesterolemia. N Engl J Med. 2008 Apr;358(14): 1431-43.

80 Bandeali SJ, Daye J, Virani SS. Novel therapies for treating familial hypercholesterolemia. Curr Atheroscler Rep. 2014 Jan;16(1):382.

81 Bays HE, Shah A, Lin J, Sisk CM, Dong Q, Maccubbin D. Consistency of extendedrelease niacin/laropiprant effects on $\operatorname{Lp}(\mathrm{a})$, ApoB, non-HDL-C, Apo A1, and ApoB/ ApoA1 ratio across patient subgroups. Am J Cardiovasc Drugs. 2012 Jun;12(3):197206.

82 Schwartz J, Padmanabhan A, Aqui N, Balogun RA, Connelly-Smith L, Delaney $\mathrm{M}$, et al. Guidelines on the use of therapeutic apheresis in clinical practice-evidence-based approach from the writing committee of the American Society for Apheresis: The Seventh Special Issue. J Clin Apher. 2016 Jun;31(3):149-62.
83 Raal FJ, Giugliano RP, Sabatine MS, Koren MJ, Langslet G, Bays H, et al. Reduction in lipoprotein(a) with PCSK9 monoclonal antibody evolocumab (AMG 145): a pooled analysis of more than 1,300 patients in 4 phase II trials. J Am Coll Cardiol. 2014 Apr;63(13): 1278-88.

84 de Gennes JL, Touraine R, Maunand B, Truffert J, Laudat P. [Homozygous cutaneotendinous forms of hypercholesteremic xanthomatosis in an exemplary familial case. Trial of plasmapheresis ans heroic treatment]. Bull Mem Soc Med Hop Paris. 1967 Dec; 118(15):1377-402.

85 Thompson GR, Lowenthal R, Myant NB. Plasma exchange in the management of homozygous familial hypercholesterolaemia. Lancet. 1975 May;1(7918):1208-11.

86 Lupien PJ, Moorjani S, Awad J. A new approach to the management of familial hypercholesterolaemia: removal of plasma-cholesterol based on the principle of affinity chromatography. Lancet. 1976 Jun; 1(7972): 1261-5.

87 Hovland A, Marcovina S, Hardersen R, Enebakk T, Mollnes TE, Lappegård KT. Three different LDL apheresis columns efficiently and equally reduce lipoprotein(a) concentrations in patients with familial hypercholesterolemia and small apolipoprotein(a) particles. Transfus Apheresis Sci. 2012 Feb;46(1): 73-6.

88 Feingold K, Grunfeld C. Lipoprotein apheresis. In: Feingold KR, Anawalt B, Boyce A, et al., editors.South Dartmouth (MA): MDText. com, Inc.; 2017.

89 Jaeger BR, Richter Y, Nagel D, Heigl F, Vogt A, Roeseler E, et al.; Group of Clinical Investigators. Longitudinal cohort study on the effectiveness of lipid apheresis treatment to reduce high lipoprotein(a) levels and prevent major adverse coronary events. Nat Clin Pract Cardiovasc Med. 2009 Mar;6(3):229-39.

90 Raina R, Krishnappa V. An update on LDL apheresis for nephrotic syndrome. Pediatr Nephrol. 2018 Sep 14.

91 Muso E, Mune M, Hirano T, Hattori M, Kimura K, Watanabe T, et al. A prospective observational survey on the long-term effect of ldl apheresis on drug-resistant nephrotic syndrome. Nephron Extra. 2015 Aug;5(2): 58-66.

92 Hattori M, Chikamoto H, Akioka Y, Nakakura $\mathrm{H}$, Ogino $\mathrm{D}$, Matsunaga $\mathrm{A}$, et al. A combined low-density lipoprotein apheresis and prednisone therapy for steroid-resistant primary focal segmental glomerulosclerosis in children. Am J Kidney Dis. 2003 Dec;42(6): 1121-30.

93 Bianchin G, Russi G, Romano N, Fioravanti P. Treatment with HELP-apheresis in patients suffering from sudden sensorineural hearing loss: a prospective, randomized, controlled study. Laryngoscope. 2010 Apr;120(4): 800-7.

94 Rietzsch H, Panzner I, Selisko T, Julius U, Jabs $\mathrm{N}$, Reimann M, et al. Heparin-induced Extra- corporal LDL precipitation (H.E.L.P) in diabetic foot syndrome - preventive and regenerative potential? Horm Metab Res. 2008 Jul; 40(7):487-90.

95 Poller WC, Berger A, Dreger H, Morgera S, Enke-Melzer K. Lipoprotein apheresis in patients with peripheral artery disease and lipoprotein(a)-hyperlipoproteinemia: 2 -year follow-up of a prospective single center study. Atheroscler Suppl. 2017 Nov;30: 174-9.

96 Wang Y, Blessing F, Walli AK, Überfuhr P, Fraunberger P, Seidel D. Effects of heparinmediated extracorporeal low-density lipoprotein precipitation beyond lowering proatherogenic lipoproteins-reduction of circulating proinflammatory and procoagulatory markers. Atherosclerosis. 2004 Jul; 175(1): 145-50.

97 Strauchmann J, Wallbach M, Bramlage C, Puls M, Konstantinides S, Mueller GA, et al. Lipoprotein apheresis reduces biomarkers of plaque destabilization and cardiovascular risk. J Clin Apher. 2014 Oct;29(5):235-42.

98 Moriarty PM, Gibson CA. Effect of low-density lipoprotein apheresis on lipoprotein-associated phospholipase A2. Am J Cardiol. 2005 May;95(10):1246-7.

99 Moriarty PM, Gibson CA, Shih J, Matias MS. C-reactive protein and other markers of inflammation among patients undergoing HELP LDL apheresis. Atherosclerosis. 2001 Oct;158(2):495-8.

100 Wieland E, Schettler V, Armstrong VW. Highly effective reduction of C-reactive protein in patients with coronary heart disease by extracorporeal low density lipoprotein apheresis. Atherosclerosis. 2002 May; 162(1):187-91.

101 Otto C, Geiss HC, Empen K, Parhofer KG Long-term reduction of $\mathrm{C}$-reactive protein concentration by regular LDL apheresis. Atherosclerosis. 2004 May; 174(1):151-6.

102 Julius U, Siegert G, Gromeier S. Intraindividual comparison of the impact of two selective apheresis methods (DALI and HELP) on the coagulation system. Int J Artif Organs. 2000 Mar;23(3):199-206.

103 Wang JW, Zhang YN, Sze SK, van de Weg SM, Vernooij F, Schoneveld AH, et al. Lowering low-density lipoprotein particles in plasma using dextran sulphate co-precipitates procoagulant extracellular vesicles. Int J Mol Sci. 2017 Dec;19(1):1-13.

104 Leitinger N, Pirich C, Blazek I, Endler G, Sinzinger H. Decreased susceptibility of low-density lipoproteins to in-vitro oxidation after dextran-sulfate LDL-apheresis treatment. Atherosclerosis. 1996 Oct;126(2): 305-12.

105 Kopprasch S, Bornstein SR, Bergmann S, Graessler J, Julius U. Long-term therapeutic efficacy of lipoprotein apheresis on circulating oxidative stress parameters-A comparison of two different apheresis techniques. Atheroscler Suppl. 2015 May; 18: $80-4$. 
106 Agishi T, Kaneko I, Hasuo Y, Hayasaka Y, Sanaka T, Ota K, et al. Double filtration plasmapheresis. Trans Am Soc Artif Intern Organs. 1980;26:406-11.

107 Bambauer R, Bambauer C, Lehmann B, Latza R, Schiel R. LDL-apheresis: technical and clinical aspects. ScientificWorldJournal. 2012;2012:314283.

108 Siami GA, Siami FS. The current status of therapeutic apheresis devices in the United States. Int J Artif Organs. 2002 Jun;25(6): 499-502.

109 Mabuchi H, Michishita I, Takeda M, Fujita H, Koizumi J, Takeda R, et al. A new low density lipoprotein apheresis system using two dextran sulfate cellulose columns in an automated column regenerating unit (LDL continuous apheresis). Atherosclerosis. 1987 Nov;68(1-2):19-25.

110 Gordon BR, Kelsey SF, Bilheimer DW, Brown DC, Dau PC, Gotto AM Jr, et al.; The Liposorber Study Group. Treatment of refractory familial hypercholesterolemia by low-density lipoprotein apheresis using an automated dextran sulfate cellulose adsorption system. Am J Cardiol. 1992 Oct;70(11): 1010-6.

111 Otto C, Kern P, Bambauer R, Kallert S, Schwandt P, Parhofer KG. Efficacy and safety of a new whole-blood low-density lipoprotein apheresis system (Liposorber D) in severe hypercholesterolemia. Artif Organs. 2003 Dec;27(12):1116-22.

112 Armstrong VW, Windisch M, Wieland $\mathrm{H}$, Fuchs C, Rieger J, Köstering H, et al. Selective continuous extracorporal elimination of low-density lipoproteins with heparin at acidic pH. Trans Am Soc Artif Intern Organs. 1983;29:323-8.

113 Eisenhauer T, Armstrong VW, Wieland H, Fuchs C, Scheler F, Seidel D. Selective removal of low density lipoproteins (LDL) by precipitation at low $\mathrm{pH}$ : first clinical application of the HELP system. Klin Wochenschr. 1987 Feb;65(4):161-8.

114 Seidel D, Armstrong VW, Schuff-Werner P. The HELP-LDL-apheresis multicentre study, an angiographically assessed trial on the role of LDL-apheresis in the secondary prevention of coronary heart disease: I. Evaluation of safety and cholesterol-lowering effects during the first 12 months. Eur J Clin Invest. 1991 Aug;21(4):375-83.

115 Armstrong VW, Schuff-Werner P, Eisenhauer T, Helmhold M, Stix M, Seidel D. Heparin extracorporeal LDL precipitation (HELP): an effective apheresis procedure for lowering Lp(a) levels. Chem Phys Lipids. 1994 Jan;67-68:315-21.

116 Seidel D, Armstrong VW, Schuff-Werner P: TheHELP囚LDL囚apheresis multicentre study, an angiographically assessed trial on the role of LDL冈apheresis in the secondary prevention of coronary heart disease: I. Evaluation of safety and cholesterol邓lowering effects during the first 12 months. Eur J Clin Invest. 1991 Aug;21(4):375-83.
117 Bosch T, Schmidt B, Blumenstein M, Gurland HJ. Lipid apheresis by hemoperfusion: in vitro efficacy and ex vivo biocompatibility of a new low-density lipoprotein adsorber compatible with human whole blood. Artif Organs. 1993 Jul;17(7):640-52.

118 Bosch T. Practical aspects of direct adsorption of lipoproteins from whole blood by DALI LDL-apheresis. Transfus Apheresis Sci. 2004 Oct;31(2):83-8.

119 Pokrovsky SN, Sussekov AV, Afanasieva OI, Adamova IY, Lyakishev AA, Kukharchuk VV. Extracorporeal immunoadsorption for the specific removal of lipoprotein (a) (Lp(a) apheresis): preliminary clinical data. Chem Phys Lipids. 1994 Jan;67-68:323-30.

120 Pokrovsky SN, Adamova IYu, Afanasieva OY, Benevolenskaya GF. Immunosorbent for selective removal of lipoprotein (a) from human plasma: in vitro study. Artif Organs. 1991 Apr;15(2):136-40.

121 Leebmann J, Roeseler E, Julius U, Heigl F, Spitthoever R, Heutling D, et al.; Pro(a)LiFe Study Group*. Lipoprotein apheresis in patients with maximally tolerated lipid-lowering therapy, lipoprotein(a)-hyperlipoproteinemia, and progressive cardiovascular disease: prospective observational multicenter study. Circulation. 2013 Dec;128(24): 2567-76.

122 Klingel R, Heibges A, Fassbender C; Pro(a) LiFe-Study Group. Prevention of cardiovascular complications in patients with $\mathrm{Lp}(\mathrm{a})$ hyperlipoproteinemia and progressive cardiovascular disease by long-term lipoprotein apheresis according to German national guidelines. Clin Res Cardiol Suppl. 2017 Mar;12(S1 Suppl 1):38-43.

123 Rosada A, Kassner U, Vogt A, Willhauck M, Parhofer K, Steinhagen-Thiessen E. Does regular lipid apheresis in patients with isolated elevated lipoprotein(a) levels reduce the incidence of cardiovascular events? Artif Organs. 2014 Feb;38(2):135-41.

124 Schatz U, Tselmin S, Müller G, Julius U, Hohenstein B, Fischer S, et al. Most significant reduction of cardiovascular events in patients undergoing lipoproteinapheresis due to raised $\mathrm{Lp}$ (a) levels - A multicenter observational study. Atheroscler Suppl. $2017 \mathrm{Nov}$; 30:246-52.

125 Khan TZ, Hsu LY, Arai AE, Rhodes S, Pottle A, Wage R, et al. Apheresis as novel treatment for refractory angina with raised lipoprotein(a): a randomized controlled cross-over trial. Eur Heart J. 2017 May; 38(20):1561-9.

126 Heigl F, Hettich R, Lotz N, Reeg H, Pflederer $\mathrm{T}$, Osterkorn D, et al. Clinical benefit of long-term lipoprotein apheresis in patients with severe hypercholesterolemia or $\mathrm{Lp}(\mathrm{a})$ hyperlipoproteinemia with progressive cardiovascular disease. Clin Res Cardiol Suppl. 2015 Apr;10 S1:8-13.

127 Schettler VJ, Neumann CL, Peter C, Zimmermann T, Julius U, Roeseler E, et al.; Scientific Board of GLAR for the German
Apheresis Working Group. Current insights into the German Lipoprotein Apheresis Registry (GLAR) - Almost 5 years on. Atheroscler Suppl. 2017 Nov;30:50-5.

128 Yamaguchi H, Lee YJ, Daida H, Yokoi H, Miyano H, Kanoh T, et al. Effectiveness of LDL-apheresis in preventing restenosis after percutaneous transluminal coronary angioplasty (PTCA): LDL-apheresis angioplasty restenosis trial (L-ART). Chem Phys Lipids. 1994 Jan;67-68:399-403.

129 Thompson GR, Maher VM, Matthews S, Kitano Y, Neuwirth C, Shortt MB, et al. Familial Hypercholesterolaemia Regression Study: a randomised trial of low-density-lipoprotein apheresis. Lancet. 1995 Apr; 345(8953):811-6.

130 Sampietro T, Sbrana F, Bigazzi F, Ripoli A, Dal Pino B, Pasanisi EM, et al. The incidence of cardiovascular events is largely reduced in patients with maximally tolerated drug therapy and lipoprotein apheresis. A single-center experience. Atheroscler Suppl. 2015 May; 18:268-72.

131 van Buuren F, Kreickmann S, Horstkotte D, Kottmann T, Mellwig KP. HELP apheresis in hypercholesterolemia and cardiovascular disease: efficacy and adverse events after 8,500 procedures. Clin Res Cardiol Suppl. 2012 Jun; 1 S1:24-30.

132 Tatami R, Inoue N, Itoh H, Kishino B, Koga N, Nakashima Y, et al.; The LARS Investigators. Regression of coronary atherosclerosis by combined LDL-apheresis and lipid-lowering drug therapy in patients with familial hypercholesterolemia: a multicenter study. Atherosclerosis. 1992 Jul;95(1):1-13.

133 Kroon AA, Aengevaeren WR, van der Werf T, Uijen GJ, Reiber JH, Bruschke AV, et al. LDL-Apheresis Atherosclerosis Regression Study (LAARS). Effect of aggressive versus conventional lipid lowering treatment on coronary atherosclerosis. Circulation. 1996 May;93(10):1826-35.

134 Safarova MS, Ezhov MV, Afanasieva OI, Matchin YG, Atanesyan RV, Adamova IY, et al. Effect of specific lipoprotein(a) apheresis on coronary atherosclerosis regression assessed by quantitative coronary angiography. Atheroscler Suppl. 2013 Jan;14(1):93-9.

135 Stefanutti C, Morozzi C, Di Giacomo S; Italian Multicenter Study on Low-Density Lipoprotein Apheresis Working Group. Italian multicenter study on low-density lipoprotein apheresis Working Group 2009 survey. Ther Apher Dial. 2013 Apr;17(2):169-78.

136 Koga N, Watanabe K, Kurashige Y, Sato T, Hiroki T. Long-term effects of LDL apheresis on carotid arterial atherosclerosis in familial hypercholesterolaemic patients. J Intern Med. 1999 Jul;246(1):35-43.

137 Kroon AA, van Asten WN, Stalenhoef AF. Effect of apheresis of low-density lipoprotein on peripheral vascular disease in hypercholesterolemic patients with coronary artery disease. Ann Intern Med. 1996 Dec; 125(12):945-54. 
138 Carallo C, Loprete A, Mazza G, Bellotti G, de Siena M, Serrao P, et al. Biphasic hemodynamic effects of LDL-apheresis in common carotid artery. Clin Hemorheol Microcirc. 2015;60(3):297-307.

139 Ezhov MV, Safarova MS, Afanasieva OI, Pogorelova OA, Tripoten MI, Adamova IY, et al. Specific Lipoprotein(a) apheresis attenuates progression of carotid intima-media thickness in coronary heart disease patients with high lipoprotein(a) levels. Atheroscler Suppl. 2015 May;18:163-9.

140 Morimoto S, Yano Y, Maki K, Sawada K, Iwasaka T. Efficacy of low-density lipoprotein apheresis in patients with peripheral arterial occlusive disease undergoing hemodialysis treatment. Am J Nephrol. 2007;27(6):643-8.

141 Nishimura H, Enokida H, Tsuruta M, Yoshino Y, Yamada Y, Sugita S, et al. Combination treatment using percutaneous transluminal angioplasty and low-density lipoprotein apheresis in a patient with peripheral arterial disease and a history of chronic hemodialysis. J Clin Apher. 2013 Aug;28(4):330-4.

142 Kamimura M, Matsuo M, Miyahara T, Kimura K, Matsumoto K, Nakaya T, et al. Improvements in artery occlusion by lowdensity lipoprotein apheresis in a patient with peripheral arterial disease. Ther Apher. 2002 Dec;6(6):467-70.

143 Bláha M, Cermanová M, Bláha V, Blažek M, Malý J, Siroký O, et al. Safety and tolerability of long lasting LDL-apheresis in familial hyperlipoproteinemia. Ther Apher Dial. 2007 Feb;11(1):9-15.
144 Koziolek MJ, Hennig U, Zapf A, Bramlage C, Grupp C, Armstrong VW, et al. Retrospective analysis of long-term lipid apheresis at a single center. Ther Apher Dial. 2010 Apr; 14(2):143-52.

145 Bramlage CP, Armstrong VW, Zapf A, Bramlage P, Mueller GA, Koziolek MJ. Lowdensity lipoprotein apheresis decreases ferritin, transferrin and vitamin B12, which may cause anemia in serially treated patients. Ther Apher Dial. 2010 Apr;14(2): 136-42.

146 Rosada A, Kassner U, Banisch D, Bender A, Steinhagen-Thiessen E, Vogt A. Quality of life in patients treated with lipoprotein apheresis. J Clin Lipidol. 2016 Mar-Apr; 10(2):323-9.e6.

147 Krieter DH, Steinke J, Kerkhoff M, Fink E, Lemke HD, Zingler C, et al. Contact activation in low-density lipoprotein apheresis systems. Artif Organs. 2005 Jan;29(1):4752 .

148 Ramlow W, Prophet H, Waitz G. Prospective crossover study for a standardized comparison of the dextrane sulfate whole blood and plasma apheresis system in patients with cardiovascular disease and severe dyslipidemia. Atheroscler Suppl. 2017 Nov;30:99-107.

149 Hohenstein B, Julius U, Lansberg P, Jaeger $\mathrm{B}$, Mellwig KP, Weiss N, et al. Rationale and design of MultiSELECt: A european multicenter study on the effect of lipoprotein(a) elimination by lipoprotein apheresis on cardiovascular outcomes. Atheroscler Suppl. 2017 Nov;30:180-6.
150 Hohenstein B, Tselmin S, Bornstein SR, Julius U. How effectively will PCSK9 inhibitors allow retrieval of freedom from apheresis in cardiovascular high risk patients? Estimates form a large single center Atheroscler Suppl. 2017 Nov;30:28-32.

151 Bigazzi F, Sbrana F, Berretti D, Maria Grazia Z, Zambon S, Fabris A, et al. Reduced incidence of cardiovascular events in hyper$\mathrm{Lp}$ (a) patients on lipoprotein apheresis. The G.I.L.A. (Gruppo Interdisciplinare Aferesi Lipoproteica) pilot study. Transfus Apher Sci. 2018 Oct;57(5):661-664.

152 Græsdal A, Bogsrud MP, Holven KB, Nenseter MS, Narverud I, Langslet G, et al. Apheresis in homozygous familial hypercholesterolemia: the results of a follow-up of all Norwegian patients with homozygous familial hypercholesterolemia. J Clin Lipidol. 2012 Jul-Aug;6(4):331-9.

153 Mellwig KP, Horstkotte D, van Buuren F. Lipoprotein (a) and coronary heart disease - is there an efficient secondary prevention? Clin Res Cardiol Suppl. 2017 Mar;12(S1 Suppl 1):18-21.

154 Sachais BS, Katz J, Ross J, Rader DJ. Longterm effects of LDL apheresis in patients with severe hypercholesterolemia. J Clin Apher. 2005 Dec;20(4):252-5.

155 von Dryander M, Fischer S, Passauer J, Müller G, Bornstein SR, Julius U. Differences in the atherogenic risk of patients treated by lipoprotein apheresis according to their lipid pattern. Atheroscler Suppl. 2013 Jan;14(1): 39-44. 